\title{
Non-Formal Education: Development of Soft Skills Education in Indonesian Society
}

\author{
Nurul Hikmah \\ Economic Education, School of Postgraduate Studies \\ Universitas Pendidikan Indonesia (UPI) \\ Bandung, Indonesia \\ nurul_hikmah@student.upi.edu
}

\author{
Sarti Hafsyah Siregar \\ Economic Education, School of Postgraduate Studies \\ Universitas Pendidikan Indonesia (UPI) \\ Bandung, Indonesia \\ sartihafsyahsiregar@gmail.com
}

\begin{abstract}
Development of soft skills education, non-formal education, and lifelong learning are important pillars in the development of education in Indonesia in accordance with Law Number 20 of 2003 on the National Education System. This study aims to analyze the educational development of soft skills in the Indonesian society in relation to lifelong learning. Development of soft skills examined are entrepreneurial ability, personality skills, and social skills. This research is based on the results of previous studies. The method used is qualitative descriptive approach using literature studies. Results from previous studies indicate that the development of soft skills education, in particular entrepreneurial skills, personality skills, and social skills are very important and need to be developed.
\end{abstract}

Keywords-soft skill education; non-formal education; lifelong learning; entrepreneurial ability; personality skills; social skills

\section{INTRODUCTION}

Education should receive attention on an ongoing basis in order to improve its quality. Improving the quality of education means improving the quality of human resources because humans are the main products of education itself. Improving the quality of human resources is a reflection of the success of a nation in advancing human civilization.

According to Law Number 20 of 2003 on the National Education System in Article 3, the national education serves to develop the ability and character development and civilization of the nation's dignity in the context of the intellectual life of the nation, is aimed at developing students' potentials in order to become a man of faith and fear of God Almighty, morals noble, healthy, knowledgeable, skilled, creative, independent, and become citizens of a democratic and accountable [1].

To realize the function and purpose of the national education, it is necessary to development of soft skills, especially entrepreneurial ability, personality skills, and social skills to Indonesian society that is needed to support the life of society. Development of soft skills can be developed in nonformal education in the context of lifelong learning.

According to the search results or formal studies that have been done, it was found that the retaining people in an $80 \%$ success is determined by its soft skills and hard skills $20 \%$ by its [2]. In line with the statement that the success of the Indonesian people in social life is also determined by factors other than hard skills, those are soft skills. This is similar to the results of research from Harvard University, United States of America, that a person's success is not determined solely by knowledge and technical abilities (hard skills), but by the skill to manage themselves and others (soft skills) [3]. Furthermore, the results of social psychology research shows that successful people in the world are determined by the role of science by $18 \%$. The remaining $82 \%$ is determined by the emotional skills, soft skills and the like [3].

Non-formal education as part of the educational system has the same task with more education (formal education) that provides the best service to the community. Programmed alternative service outside the school system can function as substitutions, additions, and complement formal education or school system.

The importance of non-formal education in Indonesia is regulated in Law Number 20 of 2003 on the National Education System in Article 26, paragraph 1 to 7 . The contents are as follows: (1) Non-formal education organized for citizens who require educational services that act as substitutes, enhancer, and/ or complement formal education in order to support lifelong education, (2) Non-formal education serves to develop the potential of learners with an emphasis on the mastery of knowledge and functional skills as well as the development of attitudes and personality professional, (3) Nonformal education includes life skills education, early childhood education, education of youth, education, empowerment of women, literacy education, vocational education and job training, education equality, as well as other education aimed at developing the ability of learners, (4) units of non-formal education consists of course institutions, training institutions, study groups, learning centers, and religion teaching forum, as well as educational unit type, (5) courses and training organized for people who need a stock of knowledge, skills, life skills, and attitudes for self-development, professional development, work, independent business, and/ or continuing education to a higher level, (6) the results of non-formal education can be appreciated on a par with the results of formal education programs after a through assessment of equivalency by the agency designated by Government or Local Government with reference to the national education standards, (7) the provisions concerning the implementation of non-formal education as referred to in paragraph (1), paragraph (2), paragraph (3), (4), subsection (5) and (6) further stipulated by government regulation [1]. 
Therefore, this study aims to analyze the educational development of soft skills, especially entrepreneurial ability, personality skills, and social skills in the Indonesian society in relation to lifelong learning.

\section{LITERATURE REVIEW}

Learning is a process of interaction between educators and learners with learning resources in a learning environment [1]. While the role of non-formal education in the context of lifelong learning services to people who really needed now and in the future. There are some roles certain communities in nonformal education those are studios of learning activities, apprentice, Productive Enterprises Pursue, religious education in the form of schools provide supplies to the students not only in the form of religious education but has begun to shift in public education, and entrepreneurial skills as the provision of life and living in the community.

Meanwhile, Klaus [4] states that the soft skills encompass personal, social, communication, and self-management behaviors, they cover a wide spectrum: self awareness, trustworthiness, conscientiousness, adaptability, critical thinking, organizational.

Soft skills are the kind of skills that is more associated with sensitivity of one's feelings on the surrounding environment. Because the soft skills associated with psychological skills, the impact of a more abstract but still can be felt, such as polite behavior, discipline, perseverance, the ability to be able to work together, helping others, and so forth. The concept of soft skills is a sociological term that represents the development of a person's emotional intelligence is a collection of personality traits, social sensitivity, communication, language, personal habits, friendliness, and optimism that characterize relationships with others [5].

Soft skills are all aspects of a generic skill that also includes cognitive elements associated with non-academic skills [6]. Soft skills concerning the categories of personal qualities, interpersonal skills, and additional skills/ knowledge, which is where all this will contribute to the ability of the overall competence [6]. Where personal qualities is the quality of a person concerning the competence of self such as creativity, ability to think and solve problems [6], while for interpersonal skills, Coates [6] states that intra-personality is skills that one has to organize itself, such as time management, stress management, change management, character transformations, creative thinking, have a positive reference purposes, and techniques learned quickly. While inter-personality is a skillrelated or interacting with the environment of expertise society and work environment as well as the interaction with people/ humans that are able to develop the performance of the maximum, the ability to motivate, leadership skills, negotiation skills, presentation skills, communication skills, ability to establish relationships, and the ability to speak in public.

In addition, it is also necessary development of entrepreneurship ability. Entrepreneurship is defined by identification of the entrepreneur and understanding the basic personality traits of entrepreneurs [7]. Entrepreneurial future of a country will be a result of an appropriate combination of talent and knowledge, taking advantage of the human capital in the best way possible [8].

Development of personality skills and social skills are also required of Indonesian society. According to Dwi [9], social skills can be defined as the ability to interact with others in social contexts through specific ways that are socially acceptable or worth and at the same time have the advantage to private and others.

\section{RESEARCH METHOD}

This research is based on the results of previous studies. The method used is qualitative descriptive approach using literature studies. In this study using analysis of literature studies. The study of literature is find references theory relevant to the case or the problems found. The reference contains about development of soft skills education examined are entrepreneurial ability, personality skills, and social skills in relation to non-formal education and lifelong learning.

References obtained and studied from journals, articles, research reports, and sites on the Internet related to the study are discussed. The output of this literature study is gathering relevant reference to the formulation of the problem. The aim is to reinforce the basic theory of the problem as well as in conducting studies and also provides a basis to conduct an evaluation related to the concept of development of soft skills education in non-formal education to Indonesian society.

After acquired the necessary reference, then is analyzed with descriptive analysis method. Descriptive analysis method is done by describing the facts are then analyzed.

\section{RESULT AND DISCUSSION}

According to Power \& Maclean [10], in embracing all forms of learning from 'cradle to grave', lifelong learning is sometimes referred to as being 'life-long and life-wide'. The definition used by the European Commission [10] is typical and one of the most widely accepted definitions among researchers and policy makers: lifelong learning is defined as: all purposeful learning activity undertaken throughout life with the aim of improving knowledge, skills and competencies within a personal, civic, social and/ or employment related perspective.

The Hamburg Declaration [10] argues the case for a new vision of education and training in which learning becomes truly life-long on the grounds that it benefits individuals and the society. Lifelong learning is important because it helps to develop the autonomy and sense of responsibility of people and communities; to reinforce the capacity to deal with the transformations taking place in the economy, in culture and in society; and to promote coexistence, tolerance and the informed and creative participation of citizens in their communities: in short to enable people and communities to take control of reviews their destiny and society to face the challenges ahead.

According to Rosana, Jumadi, \& Pujianto [11], needs to be done in order to attempt educational activities as a civilizing process, so it can be directed towards sustainable development. 
This is in line with Law Number 20 of 2003 on the National Education System Chapter III Article 4 Paragraph 3 of the education held as a civilizing process (to make people civilized) and empowering learners that goes along life. UNESCO at its meeting in 2005 recommended that the education is always directed towards sustainable development [11].

Non-formal education more speaks and acts in terms of the reality of life and community life. Its attention was focused more on efforts to help the realization of the learning process in the community. In this context, non-formal education orientation more emphasis on purpose so that people have the ability to face problems in the environment, then look for appropriate measures to solve them so that people can improve the nature and dignity of life. Thus the non-formal education is part of the recesses of people's lives to be searched and hoped his participation in the advancement of life in society, with a trade mark that distinguishes it from other educational paths [12].

The development of non-formal education one through life skills education has demonstrated its role in poverty reduction in rural areas. Life skills education in the two districts of Regency of Gunungkidul and Kulonprogo showed the poverty rate in rural areas decreased by approximately 3-6\% of the total participant's life skills education program implemented in two districts [13].

Associated with the development of lifelong learning in non-formal education, there are many ways to improve soft skills. Soft skills can be sharpened and improved by following the trainings and management seminars. Nevertheless, a powerful way to improve soft skills is a way to interact directly and do activities with others commonly called learning by doing [5].

According Djoyonegoro [14], a soft skill is a personal power to change or to handle various work problems. Learning of soft skills is seen as part of efforts to establish a professional attitude. This attitude will affect the behavior of matter to quality, precise, and efficient, appreciate the time and reputation. Soft skills can be observed through the performance, such as the ability to speak that reflect ideas and information, or explain a topic with clear, easy to understand topics that have not been known, able to interact and work cooperatively in groups. Someone with a good mastery of soft skills will reflect the capabilities that exceed the capacity of the workforce. This ability appeared due to the respective independently capable of moving the internal processes to continue to learn, try and find something that provides benefits for work or for personal development. Thus, soft skill are important to be mastered as required by a person to develop himself in doing the job.

According to Tohani [13] life skills need to be established and developed through the educational process called life skills education. Life skills education is an effort to improve the skills, knowledge, attitudes and abilities that allow citizens to learn to live independently. In the implementation of life skills education is based on the principle of the four pillars of education: learning to acquire knowledge (learning to know) followed by learning to know how to learn (learning to learn), learn to do the job (learning to do), learn to be useful person (learning to be) and learn to live together with other people (learning to live together).

Training of soft skills improve person potential, making labor more flexible, have positive attitude to changes, capable to handle change in the demands of work and more competitive [15]. In addition, soft skills are the key to success, including leadership, decision making, conflict resolution, communication, creativity, and presentation skills [16].

At the level of learning, characteristic of life skills learning are: (1) the process of identification of learning needs; (2) the awareness process to learn together; (3) the alignment of learning activities to develop self-learning, independent businesses, joint ventures; (4) the process of mastering personal, social, vocational, academic, managerial, entrepreneurial; (5) the process of providing the experience to do the job properly, resulting in product quality; (6) the process of mutual interaction to learn from experts; (7) the competency assessment process, and (8) the occurrence of technical assistance for the work and forming of joint ventures [13].

Related to soft skills education, need equal education that emphasizes the functional skill and professional personality. The curriculum in non-formal education, relate equivalency programs that target their students from among the poor, is a curriculum that is able to provide life skills and entrepreneurship in depth and professionally so that the public is ready to face the challenges of competitive future [17].

In addition, according to GEM Portugal Report [8], education and academic training are very important for entrepreneurship. It is mandatory to strengthen entrepreneurial spirit and to reduce psychological and cultural barriers within the first phases of the entrepreneurial process. Haynie et al. [8] consider that educational systems must provide to the young people better education, filling a wide range of alternatives, identification of business opportunities and exploration. Samad Aghayi [8] claims that expanding the entrepreneurial organizational culture is one of the most important factors that can play a vital role in changing people's tendency to self occupation and entrepreneurship and prepares those people who have such culture for self-occupation labor market.

In education and training for entrepreneurship, managers or organizers of the program should be implicated various important aspects related to entrepreneurship. Important aspects that support the success and failure of a process of learning in entrepreneurship education includes learning objectives, learning materials, teaching methods, facilitators and evaluation format [18].

The trait theory of entrepreneurship like the trait theory of leadership states that entrepreneurs have certain innate traits that make them capable of coming up with innovative ideas and putting them into fruition. And therefore, just like the premise that "leaders are born and not made" according to some, it is stated that entrepreneurs are born [19].

While, personality traits are commonly studied as important individual-level factors in teamwork and team performance. There are many personality tests in existence, but a commonly accepted empirical models in the social sciences is called the 
Big-Five, or equivalently the Five-Factor Model (FFM) [20]. The FFM describes a taxonomy of five personality domains which map traits that are correlated statistically. The five domains are: extraversion (outgoing, social), agreeableness (sympathetic, warm), conscientiousness (organized, dependable), emotional stability (calm, not easily upset), and openness (adventurous, creative). The FFM is based upon extensive, systematic, and rigorous empirical work, and is considered more viable as a model of personality than the wellknown Myers-Briggs personality [20].

Then social skill. According to Walker [21], social skills are a set of competencies that: a) allow an individual to initiate and maintain positive social relationships, b) contribute to peer acceptance and to a satisfactory school adjustment, and c) allow an individual to cope effectively with the larger social environment.

In a review of 28 studies using employer surveys in different countries, Cunningham and Villaseñor [22] find that socio-emotional skills are the first priority of $76.5 \%$ of the studies that rank employer skill preferences. As a result, efforts to improve these skills have become an increasing part of youth employment programs in many developing countries, especially in Latin America [22]. For example, the entra 21 program implemented in 18 Latin American countries includes a soft skills training component.

\section{CONCLUSION}

Results from previous studies, indicate that the development of soft skills education, in particular entrepreneurial skills, personality skills, and social skills are very important and need to be developed. To improve the soft skills of Indonesian society, need soft skills education to provide soft skills training in the community, especially entrepreneurial ability, personality skills, and social skills.

Soft skills training need to be encouraged because not all Indonesian people have a kind and soft skill levels the same. With soft skills training, the community will be able to work optimally and is expected to run a better social life.

\section{REFERENCES}

[1] Law Number 20 of 2003 on the National Education System (UndangUndang Nomor 20 Tahun 2003 Tentang Sistem Pendidikan Nasional).

[2] Sudiana, I Ketut, "Upaya Pengembangan Soft Skills melalui Implementasi Model Pembelajaran Kooperatif untuk Peningkatan Aktivitas dan Hasil Belajar Mahasiswa pada Pembelajaran Kimia Dasar," Jurnal Pendidikan Indonesia, vol. 1, pp. 91-101, Oktober 2012.

[3] Moma, La, "Peningkatan Soft Skills Siswa SMP melalui Pembelajaran Generatif," Cakrawala Pendidikan, pp. 248-256, Juni 2015.

[4] Suhartati, Titi., Nuraeni, Yenni., and Sixpria, Nedsal, "Studi Kebutuhan Soft Skill dalam Upaya Penyusunan Model Pembelajaran Soft Skill yang Terintegrasi dengan Mata Kuliah Akuntansi," Jurnal Akuntansi, Keuangan dan Perbankan, vol. 1, pp. 237-246, Juni 2015.

[5] Nugroho, Djoko Hari, "Integrasi Soft Skills pada Kurikulum Prodi Elektronika Instrumentasi-STTN untuk Persiapan SDM PLTN,” pp. 117-124, November 2009 [Seminar Nasional V SDM Teknologi Nuklir Yogyakarta, 2009].

[6] Utaminingsih, Sri, "Model Manajemen Pengembangan Soft Skill SMK Program Keahlian Pariwisata," Ekplanasi, vol. 6, pp. 169-183, September 2011.
[7] Prakash, Deepti. Jain, Shilpa, and Chauhan, Kavita, "Supportive Government Policies, Locus of Control and Student's Entrepreneurial Intensity: A Study of India," Journal of Global Entrepreneurship Research, vol. 5, pp.1-15, 2015.

[8] Del Rio-Rama, María de la Cruz., Peris-Ortiz, Marta., Alvarez-Garcia, José., and Rueda-Armengot, Carlos, "Entrepreneurial Intentions and Entrepreneurship Education to University Students in Portugal," Technology, Innovation and Education, vol. 2, pp. 1-11, 2016.

[9] Dwi, Santoso Agus, "Pengembangan Social Soft Skills melalui Pembelajaran Berdasarkan Masalah dalam Pembelajaran IPS pada Pemahaman Multikultural," Interaksi. vol. 01, pp. 1-8, 2013.

[10] Power, Colin Nelson and Maclean, Rupert, "Skills Development for Inclusive and Sustainable Growth in Developing Asia-Pacific, Technical and Vocational Education and Training: Issues, Concerns and Prospects 19", Chapter 2 Lifelong Learning: Meaning, Challenges, and Opportunities, pp. 29-42, 2013.

[11] Rosana, D., Jumadi., dan Pujianto, "Pengembangan Soft Skills Mahasiswa Program Kelas Internasional melalui Pembelajaran Berbasis Konteks untuk Meningkatkan Kualitas Proses dan Hasil Belajar Mekanika,” Jurnal Pendidikan IPA Indonesia, vol. 3, pp. 12-21, 2014.

[12] Gitoasmoro, Soegimin, "Peran Pendidikan Nonformal dalam Realisasi Wajib Belajar Pendidikan Dasar," Jurnal Pendidikan Dasar, vol. 6, pp. 35-46, 2005.

[13] Tohani, Entoh, "Pendidikan Nonformal dan Pengurangan Kemiskinan di Pedesaan," Walisongo, Vol. 19, pp. 385-398, November 2011.

[14] Hamidah, Siti dan Palupi, Sri, "Peningkatan Soft Skills Tanggung Jawab dan Disiplin Terintegrasi melalui Pembelajaran Praktik Patiseri," Jurnal Pendidikan Karakter, pp. 143-152, Juni 2012.

[15] Rani, E.M.S, "Need and Importance of Soft Skills in Student," Associate Professor in English, Sri Sarada College for Women, Salem, vol. II, pp. 1-6, Januari-Juni (Summer) 2010.

[16] Hamidah, Siti, "Model Pembelajaran Soft Skills Terintegrasi pada Siswa SMK Program Studi Keahlian Tata Boga," Jurnal Pendidikan Vokasi, vol. 2, pp. 53-62, Februari 2012.

[17] Slamet PH, "Pendidikan Kecakapan Hidup: Konsep Dasar,” Jurnal Pendidikan dan Kebudayaan, pp. 541-561, Juli 2002.

[18] Prasetyo, Iis, "Telaah Teoretis Model Experiential Learning dalam Pelatihan Kewirausahaan Program Pendidikan Non Formal," Majalah Ilmiah Pembelajaran, vol. 07, pp. 103-119, Oktober 2011.

[19] Qureshi, Muhammad Shahid., Saeed, Saadat., and Wasti, Syed Waleed Mehmood, "The Impact of Various Entrepreneurial Interventions During the Business Plan Competition on the Entrepreneur Identity Aspirations of Participants," Journal of Global Entrepreneurship Research, vol. 6, pp. 1-18, 2016.

[20] Rhee, Jinny., Parent, David., and Basu, Anuradha, "The Influence of Personality and Ability on Undergraduate Teamwork and Team Performance," vol. 2, pp. 1-14, 2013.

[21] Lee, Jennifer N, “The Effectiveness of Point-of-View Video Modeling as a Social Skills Intervention for Children with Autism Spectrum Disorders," vol. 2, pp. 414-428, 2015.

[22] Groh, Matthew. Krishnan, Nandini., McKenzie, David., and Vishwanath, Tara, "The Impact of Soft Skills Training on Female Youth Employment: Evidence From A Randomized Experiment In Jordan," IZA Journal of Labor \& Development, vol. 5, 2016. 